\title{
The Effect of Anxiety and Classroom Interaction on English Speaking Performance
}

\author{
Fachrukrozie Kodri \\ Perbanas Institute, Jakarta, Indonesia \\ Telp: 021-5252533, Fax: 5228460 \\ E-mail: fachruk@perbanas.id
}

\begin{abstract}
This experimental study aims to investigate the effect of anxiety and classroom interaction on English speaking performance. This research was conducted in Perbanas Institute-Jakarta involving 32 students who were selected using simple random sampling. Using Foreign Language Classroom Anxiety Scale (FLCAS), 16 students were identified as students with high anxiety and 16 other students were grouped as students with low anxiety. Then, in practicing speaking skill, a combination of students with low and high anxiety were regrouped into the controlled group which was dominated by lecturer-learners interaction and experimental group which was dominated by learner-learners interaction. Using $2 \mathrm{X}$ 2 two-way anova, the data was analysed. The findings revealed that: first, the anxiety influenced the English speaking performance; second, the classroom interaction affected English speaking performance; however, there was no interaction between anxiety and classroom interaction on English speaking performance.
\end{abstract}

Key words: anxiety, classroom interaction, English speaking performance, FLCAS

\section{INTRODUCTION}

\subsection{Background}

Language learning involves various aspects of affective factors such as motivation, attitude, personality, self confidence, etc. Anxiety is one of the psychological factors that influence the success of learning and teaching process, especially in learning to speak English. This factor has been a constraint for students to successfully learn to speak English. If it is not controlled properly, anxiety will affect negatively to the process of learning in the classroom.

Language learning in universities in Indonesia mostly focuses on reading skill. Learners have few opportunities to practice productive skills such as writing and speaking. Therefore, learners can easily feel anxious. This condition indirectly discourages them 
to involve actively in English speaking practice.

In language teaching and learning, classroom interaction is regarded as an important factor since it occurs between the lecturer and the learners or between the learners themselves, either individually or collectively to conform to the communicative situation. Then, a proper classroom interaction directed by the lecturer will help the anxious learners enhance their English speaking performance.

Based on the above reasons, this research is aimed to investigate the effect of anxiety and classroom interaction on English speaking performance.

\subsection{Research Questions}

Anxiety as a psychological factor can be a problem for students in practicing their English speaking skill. Lecturer should identify and help students to cope with this problem.

In addition, there are many factors that help students to be successful in their learning process. Classroom interaction will help students with anxiety problem to enhance their English speaking skill.

From the above identification of problems, research questions are as follow.

a. Is there any effect of anxiety on English speaking performance? b. Is there any effect of classroom interaction on English speaking performance?

c. Is there any interaction between anxiety and classroom interaction on English speaking performance?

\subsection{Purpose of the Study}

This research is aimed to identify how anxiety and classroom interaction affect students in language learning performance.

\subsection{Scope of the Study}

The research will focus on anxiety as a psychological factor during a job interview and presentation practices in the class room. Anxiety is as an independent variable. This study will also identify how classroom interaction as independent variable affects the English speaking performance. Classroom interaction is used as a treatment in this research. And the last, this research will see how the interaction between anxiety and classroom interaction is. As the dependent variable is students' English speaking performance.

\subsection{Significance of the Study}

This study has two main beneficial outcomes:

a. It provides ways for students to cope with their anxiety during speaking practice. 
b. It provides ways for students to practice English with either their classmates or lecturer.

c. It helps educators use strategies in teaching English speaking skill.

\section{REVIEW OF LITERATURE AND THEORETICAL FRAMEWORK}

\subsection{Definition of Terms}

\subsubsection{Anxiety}

The role of psychological factors in the success and failure of language learning has got a great deal of interests from many researchers. One of these factors is the role of anxiety in learning English as a foreign language (EFL).

Anxiety is categorized into trait anxiety and state anxiety, Trait anxiety is defined as a permanent tendency to show anxiety in different situation. People with high levels of trait anxiety have a general tendency to become anxious in any situation. In contrast, state anxiety is defined as a situationspecific trait anxiety; that is, an individual suffering from state anxiety will show stable anxiety but only in a certain condition (Phillips, 1992, p. 14).

Horwitz, et al (1986) introduced a theory of foreign language classroom anxiety. They believed foreign language anxiety was responsible for students' negative emotional reactions to language learning since they had to deal with a totally foreign language and culture. They considered that language anxiety is different from general anxiety and identified three components of foreign language anxiety:

1. Communication apprehension, arising from learners' inability to adequately express mature thoughts and ideas;

2. Fear of negative social evaluation, arising from a learner's need to make a positive social impression on others; and

3. Test anxiety, or apprehension over academic evaluation.

They developed their Foreign Language Classroom Anxiety Scale (FLCAS) based on these three components. To measure the anxiety, they designed the 33-item Foreign Language Classroom Anxiety Scale (FLCAS).

\subsubsection{Classroom Interaction}

In learning English, interaction is important for speaking activity. Hadfield and Hadfield (2008:105) stated that interaction involves both sending and responding to a message to other people. Learners will practice how to use a proper language to other people. Allwright (1984) stated that interaction is the fundamental fact of pedagogy which involves the successful management of classroom 
interaction. Dagarin, as cited by Nisa (2014) defined classroom interaction as a two way process between participants in the language learning process in which lecturer and learners will influence each other. Thapa and Lin (2013) said that interaction in the classroom will develop the students' linguistic resources and provide appropriate skills for speaking ability. Furthermore, interaction between lecturer and learners or a learner with their peers will develop self confidence to enhance their speaking performance. As mentioned by Smith, S.C. (2013), the ways how the lecturers socially perceive their own roles as instructors and facilitators has a significant effect on how they utilize language and interact with learners in the classrooms. This subsequently influences the way how learners interact with each other. In classroom lecturers socially construct their roles differently. They will be facilitators who help learners or instructors who teach the learners.

\subsubsection{Types of Classroom Interaction a. Teacher-Learner Interaction}

According to Harmer (1998: pp.3-4), lecturers must master the skills of interacting with their students in the learning and teaching process. A lecturer should understand how to deliver materials that are in line with his students' understanding. The ability to give feedback that students understand will ease them to interact with lecturer is considered an important skill used by lecturer in the learning and teaching process. Experienced lecturers also utilize the ability to deliver materials by using body language such as gesture, eye contact, using different intonation when guiding, asking, or answering questions.

\section{b. Learner-Learner Interactions}

Learner-Learner Interaction happens when learners interact in pairs or in small groups or bigger groups. This interaction allows students to practice speaking skills. Participants can use appropriate language functions when negotiating with colleagues, can give feedback, correct, or ask colleagues. (Mackey, 2007: 30).

\subsubsection{English Speaking Performance}

In learning English as a foreign language, learners should master the four skills: writing, reading, listening and speaking. Speaking skill which shows the increasing learners' abilities in producing oral discourses, has been defined differently. According to Bygate (1987:5), oral expression involves the use of acceptable language forms, pronouncing in a way that is alike to that of native speakers, and producing the right meanings that can be understood by the listener. For 
him, speaking is a skill that all people use when they are interacting among each other; therefore, speaking is regarded as the important skill that learners require in order to be able to speak fluently in the classroom situation. In addition to the previous definitions, Hedge (2000:261) regarded speaking as a skill by which people are judged while first impressions are being formed." This means that speaking skill is important because it reflects peoples ideas and opinions.

There are a lot of studies of the effect of anxiety on language learning. Woodrow (2006) reported that second language anxiety has a weakening effect on the oral performance of speakers of English as a second language. The findings indicate that the most frequent source of anxiety was interacting with native speakers. Evidence for two types of anxious language learner emerged; retrieval interference and skills deficit. There was an indication from the study that English language learners from Confucian Heritage Cultures (CHCs), China, Korea and Japan were more anxious language learners than other ethnic groups.

Liu and Huang (2011) examined the relationship between foreign language anxiety, English learning motivation, and performance in
English. Analyses of the data revealed that (1) the respondents generally did not feel anxious in English and were moderately motivated to learn English, (2) foreign language anxiety and English learning motivation were significantly negatively correlated with each other, and (3) both foreign language anxiety and English learning motivation were significantly correlated with students' performance in English.

Several studies were related to classroom interaction in language learning. First, the study comes from Choudhury (2005) who addressed interaction in second language classroom. The findings revealed that making learners actively participate as much as possible cannot be universally right. Then, Taous (2012) reported that classroom interaction plays an important role in developing the learners ${ }^{e e}$ oral skill because it provides opportunities for learners to practice their speaking skill inside the classroom. Also, teachers need to be aware of the importance of classroom interaction as a strategy to improve the learners' speaking ability in order to be able to suggest some pedagogical implications for them to reach good speaking level. The findings of the classroom observation and the teachers' interview have revealed that both learners and teachers consider classroom interaction as an important 
strategy in improving the speaking skill,

Mohammadi, et al (2014) investigated the effects of classroom structure on the speaking skills of Iranian EFL learners. The findings revealed that classroom structure affected speaking skills and the results also showed that there were no significant differences among the individualistic, co-operative, and the control groups.

Azadi, et al (2015) reported that classroom interaction can be considered as a way of improving the learners' speaking ability. Gender made no significant difference for the betterment of their speaking skills. Furthermore, teaching speaking strategies introduced ways of interacting and as a result could help them improve their speaking skills. Structuring the class so that it devotes most of the class time to learners interactions and encouraging in-depth conversations among them can be good ways of promoting classroom interaction.

\subsection{Theoretical Framework}

Failure in learning a foreign language can also be influenced by affective factor such as the anxiety of the participants in the learning process in the classroom. Horwitz (1986) states that anxiety in foreign languages (FLA) can be a predictor of one's success in learning a foreign language. Highly anxious students often talk nervously, forget what they want to say, be tremble or sweaty while speaking in front of the class. The participants prefer to keep silent, not having the initiative to ask or answer questions. This makes their performance look worse than their peers. It is supported by Abu-Rabia (2004) who stated that when students point out to have high level of anxiety, positively it can effect to the low level of successfulness gained by the students. So it can be said that anxiety affects the ability to speak English.

An appropriate pattern of interaction between students and lecturers or between students and other students will help highly anxious students cope with their problems while learning to speak English. For example, the lecturer should give students the opportunity to adapt in the classroom by getting them to talk to their friends either in pairs or in small groups. In addition, the lecturer is expected to be relaxed and create humor to create a relaxed atmosphere. Also motivating, encouraging, and praising participants will help grow their self-confidence and produce maximum learning performance. Therefore, it can be said that there is an interaction between anxiety and class interaction which affects the English speaking performance. 


\section{METHOD}

\subsection{Types of Research}

This research is a quantitative research using experimental design in which two types of classroom interaction are used as a treatment. Furthermore, anxiety which is categorized as high and low anxiety is used as attributive variable.

\subsection{The Operational Variables}

a. Anxiety is the scores of students after completing Foreign Language Classroom Anxiety Scale (FLCAS). The score will categorize students as those with high anxiety and low anxiety. The students with medium scores will be excluded as participants.

b. English Speaking Performance is the average scores the students gain in Job Interview test and oral presentation test during mid-term examination.

\subsection{Instruments}

Several tests are used as the instruments to obtain the data. The tests consist of:

1. Anxiety test is arranged by using The Foreign Language Classroom Anxiety Scale (FLCAS) which consists of 33-item with five-point Likert scale which was adapted from the scale developed by Horwitz, et al. The FLCAS in Indonesian version consists of 33 statements with significant part-whole correlations with the total scale, aiming to assess communication apprehension, test anxiety and fear of negative evaluation associated with language anxiety. Each item on the FLCAS is rated on a five-point Likert scale ranging from 1 (strongly agree) to 5 (strongly disagree). Total scores of the scale range from 33 to 165 with lower scores indicate higher levels of anxiety. Twenty-four of the items are positive statements, and nine of the items are negative statements. The reliability of the test is analysed by using Cronbach' Alpha statistical technique.

2. English speaking performance test is arranged by using the scoring rubric developed by Perbanas Language Center (ULBI). All the participants' average scores in the forms of Job Interview test and Oral Presentation in the Mid-term exam of English for professional Purpose (EPP) were taken in the sixth and eighth week out of sixteen classroom meetings.

\subsection{Population and Sample}

The population is 216 Perbanas Institute students majoring in S1 Business and Financial Management and $\mathrm{S} 1$ accounting programs who were taking English for Professional Purpose (EPP) subject in the even semester 2016. Thirty two respondents 
from two classes were selected by using simple random sampling. Then the sample will be divided into two groups. The first group which consists of student with high and low anxiety will practice speaking English mostly with their classmates (learner-learner interaction). In contrast, the second group which consists of students with high and low anxiety will practice speaking English mostly with their lecturer (learner-lecturer interaction).

Using Two-Way ANOVA, the students with high and low anxiety rates as the first independent variable will be correlated to English speaking performance as dependent variable. Then, students will be divided into two groups. The first group will practice speaking mostly with their classmates (learner-learner interaction), and the second group will practice their English speaking mostly with lecturer (learner-lecturer interaction). And finally, the interaction between anxiety and classroom interaction will be analysed.

\section{FINDINGS AND DISCUSSION}

\subsection{Findings}

Based on the results of the tests given to the students, then the data were analysed by using SPSS Twoway Anova. The data was reported in the tables below.
Table 1: Descriptive Data

\begin{tabular}{lcccc}
\hline $\begin{array}{l}\text { Classroom } \\
\text { Interaction }\end{array}$ & $\begin{array}{c}\text { Anxiety } \\
\text { Rate }\end{array}$ & $\mathrm{N}$ & Mean & SD \\
\hline Learner- & Low & 8 & 70.13 & 7.43 \\
Lecturer & High & 8 & 61.25 & 10.79 \\
Interaction & Total & 16 & 65.69 & 10.06 \\
Learner- & Low & 8 & 77.13 & 7.47 \\
Learner & High & 8 & 67.63 & 3.16 \\
Interaction & Total & 16 & 72.38 & 7.40 \\
Total & Low & 16 & 73.63 & 8.06 \\
& High & 16 & 64.44 & 8.36 \\
& Total & 32 & 69.03 & 9.33 \\
\hline
\end{tabular}

Table 1 showed the English speaking test scores in two groups which were divided based on the classroom interaction dominated by learners-lecturer interaction and learner-learner interaction. Each of group consists of learners with low anxiety rate and those with high anxiety rate. In learners-lecturer interaction group, the average scores of learners with low anxiety rate was 70.13 and learners with high anxiety rate was 61.25. On the other hand, in learner-learner interaction group, the average scores of learners with low anxiety rate were 77.13 and those with high anxiety rate were 67.63. Totally, the average scores of English speaking test in learners-lecturer interaction class were 65.69 ; in contrast, totally the average scores of English speaking test in learner-learner interaction class were 72.38 . 
Normality Test and Homogeneity

Test.

Before the data was analysed using two-way ANOVA, normality test and homogeneity test were performed.

Table 2: Test using One-Sample Kolmogorov-Smirnov Test

\begin{tabular}{|c|c|c|}
\hline & & $\begin{array}{c}\text { English } \\
\text { Speaking } \\
\text { Score }\end{array}$ \\
\hline \multicolumn{2}{|l|}{$\mathrm{N}$} & 32 \\
\hline \multirow{2}{*}{$\begin{array}{l}\text { Normal } \\
\text { Parameters }\end{array}$} & Mean & 69.0313 \\
\hline & $\begin{array}{l}\text { Std. } \\
\text { Deviation }\end{array}$ & 9.32733 \\
\hline \multirow{5}{*}{\multicolumn{2}{|c|}{$\begin{array}{ll}\text { Most } & \text { Absolute } \\
\text { Extreme } & \text { Positive } \\
\text { Differences } & \text { Negative } \\
\text { Test Statistic } & \\
\text { Asymp. Sig. (2-tailed) } \\
\end{array}$}} & .123 \\
\hline & & .116 \\
\hline & & -.123 \\
\hline & & .123 \\
\hline & & $200^{\mathrm{c}, \mathrm{d}}$ \\
\hline \multicolumn{3}{|c|}{$\begin{array}{l}\text { The normality test was } \\
\text { undertaken on the null hypothesis (Ho) } \\
\text { which stated that sample came from } \\
\text { normally distributed population. The } \\
\text { Null hypothesis will be accepted if } \\
\text { significance value is > } 0.05 \text {. In } \\
\text { contrast, Ho will be rejected if the } \\
\text { significance value was }<0.05 \text {. Base on } \\
\text { the test of Liliefors Significance } \\
\text { Correction of Kolmogorov-Smirnov, it } \\
\text { is evidence that significance value is } \\
0.123 \text { and the Asymp sig is } 0.2 \text {. } \\
\text { Because the Asymp sig value is } 0.2> \\
0.05 \text {, Ho was accepted. It means that } \\
\text { the data was normally distributed. }\end{array}$} \\
\hline
\end{tabular}

Table 3: Homogeneity Test: Levene's Test of Equality of Error Variances $^{\mathrm{a}}$

\begin{tabular}{cccc}
\hline F & df1 & df2 & Sig. \\
\hline 2.511 & 3 & 28 & .079 \\
\hline
\end{tabular}

The second prerequisite test was the homogeneity test. This test showed that two or more groups of samples come from populations having the same variance. The testing of homogeneity of the sample variance used Levene's Test with a significance level of 0.05 . Testing criteria to determine the homogeneity of variance were conducted by comparing the results count towards learning outcomes with the significance level of 0.05 . If the significance value is > 0.05 , it can be stated that the sample data comes from populations having the same variance, or they are homogeneous. The results of the statistical analysis showed that the significance value is 0.079 which means it is greater than 0.05 . It implies that the sample variances are homogeneous.

Based on the normality test and homogeneity test, the samples selected have met the assumption of normal and homogenous data. It means that the data is able to be analysed using two-way Anova. 
Table 4: Summary of BetweenSubjects Effects

Dependent Variable:

\begin{tabular}{|c|c|c|c|c|c|}
\hline $\begin{array}{c}\text { Sourc } \\
\text { e of } \\
\text { Varia } \\
\text { tion }\end{array}$ & $\begin{array}{c}\text { Sum } \\
\text { of } \\
\text { Squa } \\
\text { res }\end{array}$ & $\begin{array}{l}\text { d } \\
\text { f }\end{array}$ & $\begin{array}{c}\text { Mean } \\
\text { Squar } \\
\text { e }\end{array}$ & $\mathbf{F}$ & $\begin{array}{l}\mathrm{Si} \\
\text { g. }\end{array}$ \\
\hline $\begin{array}{l}\text { Corre } \\
\text { cted } \\
\text { Model }\end{array}$ & $\begin{array}{r}1033, \\
844^{\mathrm{a}}\end{array}$ & 3 & $\begin{array}{r}344.6 \\
15\end{array}$ & $\begin{array}{r}5.80 \\
2\end{array}$ & $\begin{array}{l}.0 \\
0 \\
3\end{array}$ \\
\hline $\begin{array}{l}\text { Interc } \\
\text { ept }\end{array}$ & $\begin{array}{r}1524 \\
90.03 \\
1\end{array}$ & 1 & $\begin{array}{r}15249 \\
0.031\end{array}$ & $\begin{array}{r}2567 \\
.288\end{array}$ & $\begin{array}{l}.0 \\
0 \\
0\end{array}$ \\
\hline $\begin{array}{l}\text { A } \\
\text { Factor } \\
\text { (AR) }\end{array}$ & $\begin{array}{r}675.2 \\
81\end{array}$ & 1 & $\begin{array}{r}675.2 \\
81\end{array}$ & $\begin{array}{r}11.3 \\
69\end{array}$ & $\begin{array}{l}.0 \\
0 \\
2\end{array}$ \\
\hline $\begin{array}{l}\text { B } \\
\text { Factor } \\
\text { (CI) }\end{array}$ & $\begin{array}{r}357.7 \\
81\end{array}$ & 1 & $\begin{array}{r}357.7 \\
81\end{array}$ & $\begin{array}{r}6.02 \\
4\end{array}$ & $\begin{array}{l}.0 \\
2 \\
1\end{array}$ \\
\hline $\begin{array}{l}\mathrm{AB} \\
\text { Factor } \\
(\mathrm{AR} \\
\left.{ }^{*} \mathrm{CI}\right)\end{array}$ & .781 & 1 & .781 & .013 & $\begin{array}{l}.9 \\
1 \\
0\end{array}$ \\
\hline $\begin{array}{l}\text { Withi } \\
\mathrm{n} \text { or } \\
\text { Error }\end{array}$ & $\begin{array}{r}1663 . \\
125\end{array}$ & $\begin{array}{l}2 \\
8\end{array}$ & $\begin{array}{r}59.39 \\
7\end{array}$ & & \\
\hline Total & $\begin{array}{r}1551 \\
87.00 \\
0\end{array}$ & $\begin{array}{l}3 \\
2\end{array}$ & & & \\
\hline $\begin{array}{l}\text { Corre } \\
\text { cted } \\
\text { Total }\end{array}$ & $\begin{array}{r}2696 . \\
969\end{array}$ & $\begin{array}{l}3 \\
1\end{array}$ & & & \\
\hline
\end{tabular}

a. $\mathrm{R}$ Squared $=, 383$ (Adjusted $\mathrm{R}$ Squared $=, 317$ )
The main effect of Anxiety Rate on English speaking performance:

This explains whether anxiety rate influences English speaking performance or not. Null hypothesis will be accepted if sig value is $>0.05$. In contrast, the null hypothesis will not be accepted if the sig score is $<0.05$. From the above table, Sig AR (Anxiety Rate) is $0.02<0.005$. Therefore Null hypothesis was not accepted. It means that anxiety rate influences English speaking performance significantly.

\section{The main effect of Classroom Interaction on English speaking performance:}

This shows whether or not classroom interaction influences English speaking performance. Null hypothesis will be accepted if sig value is $>0.05$; in contrast null hypothesis will not be accepted if sig value is < 0.05 . From the table, it can be seen that sig CI ( Classroom Interaction) is 0.021 which is $<0.05$. Therefore Ho is not accepted. It means that interaction influences English speaking performance significantly.

The interaction between Classroom Interaction and Anxiety Rate on English speaking performance:

This show whether there is an interaction between anxiety rate and classroom interaction toward English speaking performance. Null hypothesis 
will be accepted if sig value is $>0.05$. In contrast, null hypothesis will be not be accepted if sig value is $<0.05$. From the above table, it can be seen that sig value of $\mathrm{AR} * \mathrm{CI}$ is 0.91 which is > 0.05. Therefore Ho was accepted. It can be concluded that interaction between anxiety rate and classroom interaction does not influence English speaking performance. For this reason, post-hoc analysis is not necessary.

\subsection{DISCUSSION}

The research result has shown that anxiety affects the English speaking performance. This result confirmed the research finding reported by Woodrow (2006); Liu and Huang (2011).

In addition, the research result has shown that classroom interaction affects the English speaking performance. This finding has supported the study conducted by Choudury (2005), Taous (2012), Mohammadi (2014), and Azadi (2015) who reported the same result.

However, the research found that there was no interaction between classroom interaction and anxiety toward English speaking performance. Furthermore, this study could not determine which type of interaction was more dominant. This finding confirms the study held by Ayu and Nadhia (2008) who reported that English language anxiety is multi- dimensional as it affects students differently depending on the context of the situation. The respondents' anxiety levels vary depending on the situation. This result is also supported by the study of Pappamihiel (2002) who revealed that English language anxiety is of a dynamic nature where it can possibly affect students in many different ways. Similarly, Li (2014) found that learners' cognitive process in language learning is more complex and may affect their choice of learning strategies and learning outcome. Therefore, it should be taken into consideration when they are involved in different situations of interaction. In other words, the anxiety and classroom interaction do not always influence each other. The interaction occurs only on certain condition and context.

\section{CONCLUSION}

\subsection{Conclusion}

From data, it can be concluded that anxiety of students can affect the English speaking performance. It can be seen from the above table on which Sig AR (Anxiety Rate) is $0.02<0.005$. Similarly, the classroom interaction also affects the English speaking performance as it can be seen that sig CI ( Classroom Interaction) is 0.021 which is $<0.05$. Therefore Ho is not accepted.

On the other hand, the findings revealed that there was no interaction 
between Anxiety and Classroom interaction. From the above table, it can be seen that sig value of $\mathrm{AR} * \mathrm{CI}$ is 0.91 which is $>0.05$. Therefore Ho was accepted.

The data indicated that there was no interaction between anxiety and classroom interaction.

\subsection{SUGGESTIONS}

In dealing with the students' anxiety problems in speaking English, the researcher gives some suggestions such as the following.

1. From the students' point of view, they should be able to recognize their feeling of anxiety and identify the causes of their anxiety. Knowing what and why it happens will help them find ways how to cope with this situation.

2. Lecturers should encourage students to speak English by giving praises, motivations, and driving them to show their best efforts.

3. Lecturer should be able to develop a pleasant atmosphere in the classroom so that the students will feel more relaxed in the learning and teaching process.

4. Lecturer should direct the class into more student-oriented activities. Discussion in pairs and small class, task-based learning will gradually help anxious students to feel more relaxed.

5. Questioning students will help force them to answer questions.
This means that they should think be more ready to answer questions.

6. Speaking practice consumes much time in the classroom. Assignment using technology such as delivering individual presentation in a video will help students practice speaking.

\section{REFERENCES}

Abu-Rabia, S. 2004. "Teachers' role, learners' gender differences, and FL anxiety among seventh grade students studying English as a FL." Educational Psychology, Vol. 24, No 5, pp. 711-721

Allwright, D and K. M, Bailey. 1991. Focus on the Language Classroom. Cambridge:

Cambridge University Press.

Azadi, Somayeh, Mohammad Aliakbari, and Akbar Azizifar. 2015." The role of classroom interaction on improvement of speaking among Iranian EFL learners." International Journal of Language Learning and Applied Linguistics World (IJLLALW). Vol. 8, no.1, pp. 126---135

Bygate, M. 1987. Speaking. New York: Oxford University Press 
Candlin, $\mathrm{CN}$ and Widdowson,HG. 1987. Language Teaching: A Scheme for Teacher Education. Oxford: Oxford University Press.

Choudhury, S. 2005. "Interaction in second language classrooms." BRAC University Journal, Vol.2, No. 1 , pp. $77-82$.

Hadfield, J and C, Hadfield. 2008. Introduction to Teaching English. Oxford: Oxford University Press.

Harmer, J. 1998. How to Teach English. Pearson Education: Longman.

Harmer, J. 2001. The Practice of English Language Teaching. Pearson Education: Longman.

Hedge, T. 2000. Teaching and Learning in the Language Classroom. Oxford: Oxford University Press.

Horwitz, E. K., Horwitz, M.B., and Cope, J.1986. "Foreign Language Classroom Anxiety." The Modern Language Journal, Vol. 70, pp. 725-732.

Li, Xueping . 2014. "Review on effects of interaction on learners' language production." World Journal of English Language Vol. 4, No. 3; doi:10.5430 /wjel.v4n3p38.

URL:http://dx.doi.org/10.5430/wj

el. v4n3p38

Liu, Meihua and Wenhong Huang. 2011 "An exploration of foreign language anxiety and English learning motivation." .Education Research International. Vol. 2011, Article ID 493167, 8 pages. doi:10.1155/2011/493167.

Mackey, A. 2007. Conversational Interaction in Second Language Acquisition. Oxford: Oxford University Press.

Mohammadi, H., Gorjian, B., and Pazhakh, A. 2014. "The effect of classroom structure on speaking skills of Iranian EFL learners: A comparative study." International journal of language learning and applied linguistic world (IJLLALW). Vol. 5, No. 1, pp. 472 $-487$.

Nisa, Sinta Hoerun. 2014. "Classroom interaction analysis: English review" in Journal of English Education. Vol. 2, No. 2.

Phillips, Elaine.M. 1992. The Effects of Language Anxiety on Students' Oral Test Performance and Attitudes. Modern Language Journal. Vol 76, No. 1. Pp. 1425. 
Rita, Ayu and Nadhia Dalila. 2008. Anxiety and speaking English as second language Among male and female business students in Universiti Industry Selangor, retrieved from http://onlinereview. segi.edu.my/chapters/vol2_chap7 .pdf

Smith, S.C. 2013. "Classroom interaction and pedagogic practice: A Bernsteinian analysis." International Journal of Sociology of Education, Vol. 2, No. 3, pp. 263-291. doi: 10.4471/rise. 2013.34

Taous, Batite. 2012. The Role of Classroom Interaction in Improving the students' Speaking Skill: Case study of Third Year LMD Students of English at Biskra University (Master Thesis). Mohammed
Kheider University of Biskra, Faculty of letters and Languages, Department of foreign languages, Division of English, Algeria, retrieved from http://dspace.univbiskra.dz:8080/jspui/bitstream /123456789/4807/1/memoire.pdf

Thapa, C. B. and Lin, A. M. Y. (2013). Interaction in English language classrooms to enhance students'language learning. Retrieved from https: $/ /$ neltachoutari.wordpress.com /2013/08/01/ inter action-inenglish-language-classrooms-toenhance-nepalese-studentslanguage-learning/

Woodrow, Lindy. 2006. “ Anxiety and speaking English as a second language." RELC Journal 2006; Vol. 37, No 3. DOI: 10.1177/0033688206071315. 